\title{
The IL-10 (-627 A/C) Promoter Polymorphism May Be Associated With Coronary Aneurysms and Low Serum Albumin in Korean Children With Kawasaki Disease
}

\author{
HYUN-SEUNG JIN, HYO BIN KIM, BONG SEONG KIM, JONG-KEUK LEE, EUL-JU SEO, HAN-WOOK YOO, IN SOOK PARK, \\ YOUNG MI HONG, AND SOO-JONG HONG
}

\begin{abstract}
Departments of Pediatrics [H.S.J., B.S.K., J.K.L., H.W.Y., I.S.P., S.J.H.] and Laboratory Medicine [E.J.S.], College of Medicine, Ulsan University, Asian Medical Center, Seoul 138-736, Korea; Department of Pediatrics [H.B.K.], Inje University Sanggye Paik Hospital, Seoul 139-707, Korea; Department of Pediatrics [Y.M.H.], Ewha Womans University Hospital, Seoul 158-710, Korea
\end{abstract}

\begin{abstract}
Kawasaki disease (KD) is an acute febrile vasculitic syndrome of unknown etiology that preferentially affects the coronary artery. Interleukin-10 (IL-10) is a key proinflammatory cytokine, and a polymorphism near the major transcriptional start site of the IL-10 gene was shown to influence IL-10 production in vitro. This study investigated the association of the IL-10 promoter polymorphism with KD and its clinical parameters in Korean children. A total of 194 children with congenital heart disease (CHD) and 95 children with KD were included in this study. IL-10 (-627 A/C) polymorphism genotypes were determined using the single-base extension method. There was no difference in the allele frequencies of IL-10 (-627 A/C) polymorphism between CHD children and KD children. KD children with one or two copies of the IL-10 (-627C) allele showed significantly lower albumin levels $(p=0.020)$ and higher frequencies of early coronary artery aneurysm $[62.22 \%$ versus $37.78 \%$, adjusted odds ratio $(\mathrm{aOR})=3.50,95 \%$ confidence interval (CI): 1.50-8.16] compared with KD children with the common IL-10 (-627A) allele. These findings suggest that the IL-10 (-627 $\mathrm{A} / \mathrm{C}$ ) promoter polymorphism might be a genetic marker for the risk of early coronary artery complication in KD. (Pediatr Res 61: 584-587, 2007)
\end{abstract}

$\mathrm{K}^{\mathrm{D}}$ D is an acute, self-limiting vasculitis of unknown etiology that occurs predominantly in infants and young children. KD is characterized by widespread vascular inflammation of the coronary artery and other medium-sized arteries $(1,2)$. Coronary artery lesions, including coronary artery dilatation or aneurysm, are the most common complications and develop in approximately $20 \%-25 \%$ of untreated children with KD (3). Even after high-dose intravenous immunoglobulin (IVIG) therapy, coronary artery lesions occur in a small percentage of KD patients, occasionally leading to lifethreatening complications (e.g. myocardial infarction) and/or acquired heart diseases such as myocardial dysfunction, valvular diseases, and arrhythmias $(4,5)$.

Received October 23, 2006; accepted January 9, 2007.

Correspondence: Soo-Jong Hong, M.D., Department of Pediatrics, Ulsan University, College of Medicine, Asan Medical Center, Pungnap-2dong, Songpa-gu, Seoul, 138-736, Republic of Korea; e-mail: sjhong@amc.seoul.kr

This study was sponsored by grants from the Korean Ministry of Health and Welfare (01-PJ10-PG6-01GN15-0001).

DOI: $10.1203 /$ pdr.0b013e3180459fb5
$\mathrm{KD}$ is a mysterious disease of unknown etiology that has been attributed to an infection-immunogenetic-based pathogenesis believed to be the combined effects of infectious agents, host immune dysregulation, and genetic susceptibility. Numerous genetic polymorphisms have been associated with $\mathrm{KD}$ in different populations, including single nucleotide polymorphisms in the monocyte chemoattractant protein 1 gene regulatory region, and the genes encoding methylenetetrahydrofolate reductase, angiotensin I converting enzyme genotype II82, SLC11A1 (formerly NRAMP1) gene83, and IL-1 R $\alpha$ $(6-10)$. In addition, other gene polymorphisms have been associated with an important common complication of $\mathrm{KD}$, coronary artery aneurysm. These include polymorphisms in the genes encoding mannose-binding lectin, vascular endothelial growth factor, and CD14, as well as in the promoter region of the gene encoding metalloproteinase-3 (11-14).

Acute KD is associated with systemic immune activation, including elevated serum levels of IL-1, tumor necrosis factor $\alpha$, interferon- $\gamma$, IL-4, IL-6, IL-8, IL-10, and a variety of other cytokines (15-19) that are believed to play important roles in the onset of KD and the development of coronary artery lesions. Of them, IL-10 is a cytokine synthesis regulatory factor that is produced by Th2 cells and regulates cytokine production from Th1 or Th2 cells. Elevated plasma IL-10 levels have been observed in KD patients, prompting researchers to speculate that IL-10 may be involved in the pathogenesis of KD (20-23). The gene encoding IL-10, located at chromosome $1 \mathrm{q} 32$, is under the control of a promoter region harboring several genetic polymorphisms (e.g. -627 A/C) that appear to affect plasma levels of IL-10 (24-26).

Previous studies have showed that IL-10 gene polymorphisms were associated with the development of multiple diseases and other conditions, including alcoholic liver disease, atopic bronchial asthma, rheumatoid arthritis (27-32), renal disease in systemic lupus erythematosus, and response to interferon in chronic hepatitis C. However, no previous study has evaluated the association between KD and the IL-10 (-627 $\mathrm{A} / \mathrm{C}$ ) promoter polymorphism.

Abbreviations: ALT, alanine aminotransferase; AST, aspartate aminotransferase; CHD, congenital heart disease; CRP, C-reactive protein; IVIG, intravenous immunoglobulin; KD, Kawasaki disease; WBC, white blood cell 
In the present study, we investigated whether the IL-10 $(-627 \mathrm{~A} / \mathrm{C})$ promoter polymorphism is associated with the development of KD in Korean children and further assessed possible correlations with early coronary artery aneurysms or with clinical risk factors for KD.

\section{MATERIALS AND METHODS}

Subjects. We enrolled patients with KD from the Department of Pediatrics at the Asan Medical Center and Ewha Womans University Hospital, Seoul, Korea. The study group included 95 patients (56 males and 39 females, $39.99 \pm$ 33.85 mo old), all of whom met the criteria proposed by the Japanese Kawasaki Disease Research Committee (33) (Table 1). Echocardiographs were obtained by the pediatric cardiologist before or within 2 wk of IVIG administration. Coronary artery aneurysm was diagnosed from the echocardiograms using the criteria proposed by the Japanese Kawasaki Disease Research Committee (33): coronary arteries were classified as abnormal if the internal lumen diameter was $>3 \mathrm{~mm}$ in children younger than $5 \mathrm{y}$ old or $>4$ $\mathrm{mm}$ in children older than $5 \mathrm{y}$ old, if the internal diameter of a segment measured $\geq 1.5$ times that of an adjacent segment, or if the coronary lumen was clearly irregular. Of the 95 enrolled patients, 45 were identified as having coronary artery aneurysms. The control group consisted of 194 children with CHD (88 males and 106 females, $29.01 \pm 41.52 \mathrm{mo}$ ). Laboratory data were obtained for each child, including white blood cell (WBC) count, platelet count, alanine aminotransferase (ALT) level, aspartate aminotransferase (AST) level, serum total protein, serum albumin, and C-reactive protein (CRP). All blood samples were drawn before IVIG therapy in the KD patient group. The ethics committee of the Asan Medical Center and Ewha Womans University Hospital Institutional Review Board approved the study, and written informed consents were obtained from the parents of all subjects.

Genotyping of the IL-10 (-627 A/C) promoter polymorphism. The SNP in the IL-10 (-627A/C) promoter region was genotyped using the single-base extension method. Polymerase chain reaction (PCR) was performed in reaction mixtures containing $1.25 \mathrm{pmol}$ of each primer (5'-GGT AAA GGA GCC TGG AAC ACA TC-3' and 5'-GCC CTT CCA TTT TAC TTT CCA GAG A-3'), $50 \mathrm{ng}$ of genomic DNA, $250 \mathrm{mM}$ deoxyribonucleoside triphosphate, and $0.15 \mathrm{U}$ TaqDNA polymerase (Applied Biosystems, Foster City, CA) in the buffer provided by the manufacturer. Amplification was performed in a GeneAmp PCR System 9700 thermal cycler (Applied Biosystems). To clean up the PCR products for the primer extension reaction, each reaction mixture was incubated with $1 \mathrm{U}$ of shrimp alkaline phosphatase (SAP) (Amersham Life Sciences, Cleveland, $\mathrm{OH}$ ) and $2 \mathrm{U}$ of ExoI (Amersham Life Sciences) for $1 \mathrm{~h}$ at $37^{\circ} \mathrm{C}$ and then at $72^{\circ} \mathrm{C}$ for $15 \mathrm{~min}$ for enzyme inactivation. The primer extension reactions were performed with a SNaP Shot Dideoxyribonucleoside Triphosphate Primer Extension Kit (Applied Biosystems), according to the

Table 1. Clinical characteristics of study subjects

\begin{tabular}{lccr}
\hline Clinical parameters* & $\begin{array}{c}\text { Children with } \\
\text { CHD }(n=194)\end{array}$ & $\begin{array}{c}\text { Children with } \\
\text { KD }(n=95)\end{array}$ & \multicolumn{1}{c}{$p$} \\
\hline Sex, M/F & $88 / 106$ & $56 / 39$ & 0.030 \\
Mean age, mo & $29.01 \pm 41.52$ & $39.99 \pm 33.85$ & $<0.001$ \\
WBC, $\times 10^{3} / \mathrm{mm}^{3}$ & $10.34 \pm 3.82$ & $14.29 \pm 6.27$ & $<0.001$ \\
WBC peak, $\times 10^{3} / \mathrm{mm}^{3}$ & $\mathrm{NA}$ & $15.07 \pm 6.50$ & \\
Neutrophil, $\%$ & $38.32 \pm 16.46$ & $64.11 \pm 18.84$ & $<0.001$ \\
Hemoglobin, g/dL & $12.95 \pm 2.01$ & $11.49 \pm 1.21$ & $<0.001$ \\
Platelet, $\times 10^{3} / \mathrm{mm}^{3}$ & $323.20 \pm 100.47$ & $378.79 \pm 147.85$ & 0.001 \\
CRP, mg/dL & NA & $10.78 \pm 7.34$ & \\
CRP peak, mg/dL & NA & $11.18 \pm 7.42$ & \\
ESR, mm/h & NA & $58.85 \pm 32.17$ & \\
AST, IU/L & $42.58 \pm 24.05$ & $71.41 \pm 88.16$ & 0.300 \\
ALT, IU/L & $21.86 \pm 17.12$ & $84.76 \pm 102.57$ & $<0.001$ \\
Protein, g/dL & $6.30 \pm 0.80$ & $6.94 \pm 0.73$ & $<0.001$ \\
Albumin, g/dL & $3.89 \pm 0.59$ & $3.41 \pm 0.64$ & $<0.001$ \\
Total fever duration, d & NA & $7.32 \pm 3.26$ & \\
Early coronary artery & NA & $47(48.5)$ & \\
$\quad$ aneurysm, no $\%)$ & & & \\
\hline
\end{tabular}

The significance of clinical parameters according to groups was analyzed using Mann-Whitney test. NA, not available,

*Data for each group are expressed as mean \pm standard deviation (SD). manufacturer's instructions. The primer extension reactions were cleaned up by incubation at $37^{\circ} \mathrm{C}$ for $1 \mathrm{~h}$ in the presence of $1 \mathrm{U}$ of SAP, followed by incubation at $72^{\circ} \mathrm{C}$ for $15 \mathrm{~min}$. The extension products were then mixed with Genescan $120 \mathrm{Liz}$ size standard solution (Applied Biosystems) and Hi-Di formamide (Applied Biosystems), incubated for $5 \mathrm{~min}$ at $95^{\circ} \mathrm{C}$, placed on ice for $5 \mathrm{~min}$, and then electrophoresed on an ABI Prism 3100 Genetic Analyzer (Applied Biosystems). The results were analyzed using the ABI Prism GeneScan and Genotyper (Applied Biosystems) software.

Statistical analysis. Clinical phenotypes, including WBC counts, platelet counts, ALT, AST, serum total protein, serum albumin, CRP, and total duration of fever, were each analyzed as a quantitative trait. Differences in clinical phenotypes between groups were analyzed using the Mann-Whitney test according to their distribution patterns. For analysis of associations between genotypes and KD or coronary artery aneurysm, a dominant model was assumed because only a small proportion of individuals were homozygous for the risk allele. A $p$ value $<0.05$ was considered statistically significant. SPSS $12.0 \mathrm{~K}$ for Windows (SPSS Inc., Chicago, IL) was used for all statistical analyses.

\section{RESULTS}

Allele frequencies of the $I L-10(-627 \mathrm{~A} / \mathrm{C})$ polymorphism in children with $K D$ and $C H D$. In this study, 194 children with CHD and 95 children with KD were examined for their allele frequencies at the IL-10 (-627 A/C) polymorphism. The genomic frequencies of the IL-10 (-627 A/C) polymorphism in children with CHD were $50.00 \%$ (97/194) for AA, 39.18\% (76/194) for AC, and $10.82 \%$ (21/194) for CC. In children with $\mathrm{KD}$, these frequencies were $53.68 \%$ (51/95) for AA, $35.79 \%$ (34/95) for AC, and $10.53 \%$ (10/95) for CC. The genomic and allelic frequencies at this polymorphism did not significantly differ between children with CHD and KD $(\mathrm{aOR}=0.86,95 \%$ CI: 0.76-2.04) (Table 2).

Association between the IL-10 (-627 A/C) polymorphism and clinical parameters in children with $K D$ and $C H D$. There were no significant differences in the tested clinical parameters among CHD children with genotypes AA, AC, and CC (Table 3). There were also no significant differences in age at illness, WBC count, peak WBC count, neutrophil count, hemoglobin level, platelet count, CRP, peak CRP, ALT, AST, serum total protein, and total fever duration among KD children with genotypes AA, AC, and CC. In contrast, the mean serum albumin level in $\mathrm{KD}$ children with the $\mathrm{AC}$ and $\mathrm{CC}$ genotypes was significantly lower than that of KD children with genotype AA $(3.06 \pm 0.52 \mathrm{~g} / \mathrm{dL}$ versus $3.34 \pm 0.30$ $\mathrm{g} / \mathrm{dL} ; p=0.005$ ), and it also was significantly lower than the mean serum albumin level in CHD children with genotypes $\mathrm{AA}(3.06 \pm 0.52 \mathrm{~g} / \mathrm{dL}$ versus $3.93 \pm 0.60 \mathrm{~g} / \mathrm{dL} ; p<0.001)$ and genotype $\mathrm{AC}+\mathrm{CC}(3.06 \pm 0.52 \mathrm{~g} / \mathrm{dL}$ versus $3.86 \pm 0.58$ $\mathrm{g} / \mathrm{dL} ; p<0.001)($ Table 3$)$.

Table 2. Allele frequencies of the IL-10 (-627 A/C) polymorphism in children with $K D$ and children with $C H D$

\begin{tabular}{lccc}
\hline & & \multicolumn{2}{c}{$\begin{array}{c}\text { Children with KD } \\
(n=95)\end{array}$} \\
\cline { 3 - 4 } \multicolumn{1}{c}{ Loci } & $\begin{array}{c}\text { Children with CHD } \\
(n=194), \text { no. }(\%)\end{array}$ & No. $(\%)$ & aOR $(95 \%$ CI $)$ \\
\hline IL-10 (-627 A/C) & & & \\
AA & $97(50.00)$ & $51(53.68)$ & 1.00 \\
AC & $76(39.18)$ & $34(35.79)$ & $0.85(0.50-1.44)$ \\
CC & $21(10.82)$ & $10(10.53)$ & $0.91(0.40-2.08)$ \\
AC+CC & $97(50.00)$ & $44(46.32)$ & $0.86(0.76-2.04)$ \\
Frequency (A) & 0.70 & 0.72 & \\
\hline
\end{tabular}


Table 3. Association between IL-10 (-627 A/C) alleles and clinical parameters in children with KD and children with CHD

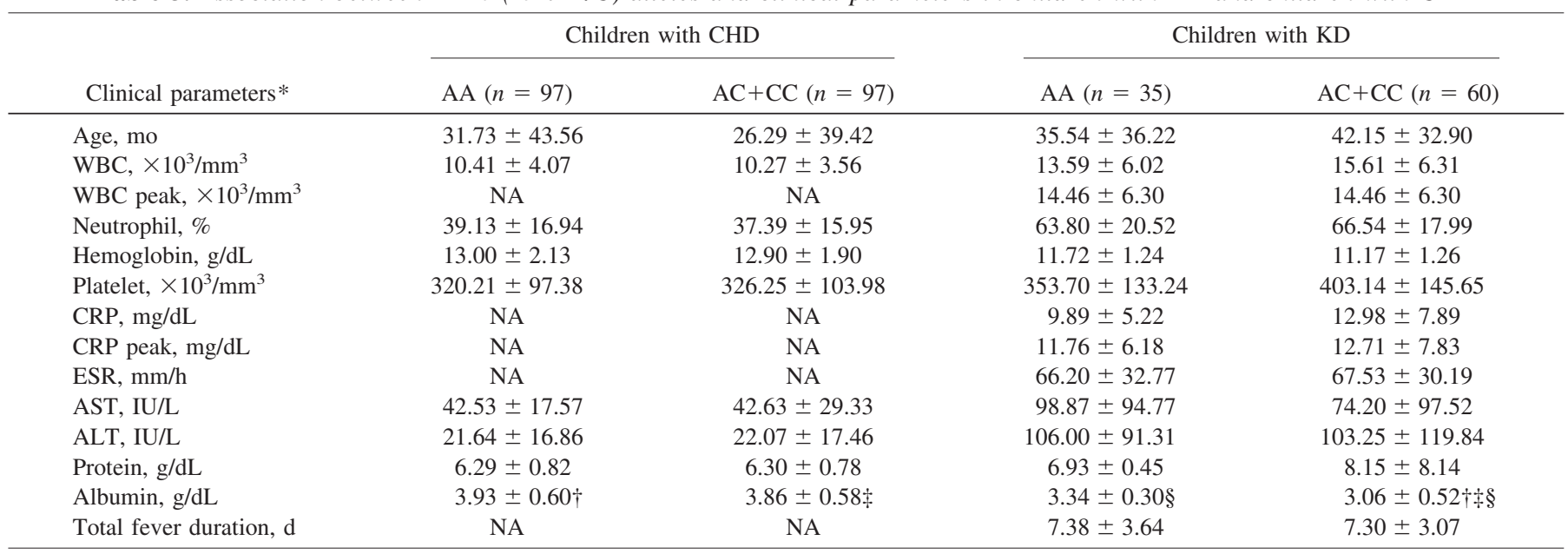

The significance of clinical parameters according to group was analyzed using the Mann-Whitney test.

*Data for each group are expressed as mean $\pm \mathrm{SD}$.

$\dagger p<0.001$; compared between AA genotype in children with CHD and AC+CC genotype in children with KD.

$\ddagger p<0.001$; compared between $\mathrm{AC}+\mathrm{CC}$ genotype in children with CHD and AC+CC genotype in children with $\mathrm{KD}$.

$\S p=0.005$; compared between AA and $\mathrm{AC}+\mathrm{CC}$ genotype in children with $\mathrm{KD}$.

Allele frequencies of the $I L-10(-627 \mathrm{~A} / \mathrm{C})$ polymorphism in $\mathrm{KD}$ children with and without early coronary artery aneurysms. We next examined whether the IL-10 (-627 A/C) polymorphism was a risk factor for early coronary artery aneurysms in children with KD. Our association analysis revealed that early coronary artery aneurysms were significantly more frequent in $\mathrm{KD}$ children harboring one or two copies of the $\mathrm{C}$ allele $(62.22 \%)$ than in children homozygous for the A allele (37.78\%; aOR $=3.50,95 \%$ CI: $1.50-8.16)$. This finding suggests that the $(-627 \mathrm{C})$ allele of the IL-10 promoter polymorphism might be associated with the risk of early coronary aneurysmal changes in KD (Table 4).

\section{DISCUSSION}

Consistent with the finding that IL-10 is involved in the pathophysiology of KD (20-23), especially in the development of coronary artery aneurysm, our analysis revealed that the risk allele of the IL-10 (-627 A/C) promoter polymorphism was significantly more frequent in Korean KD children with early coronary artery aneurysm than in those without early coronary artery aneurysm. In addition, $\mathrm{KD}$ children with the risk allele at the IL-10 (-627 A/C) promoter polymorphism were found to have lower levels of serum albumin than those with the common allele. These findings suggest that the IL-10

Table 4. Allele frequencies of the IL-10 (-627 A/C) polymorphism in KD children with and without early coronary artery aneurysm

\begin{tabular}{|c|c|c|c|}
\hline \multirow[b]{2}{*}{ Loci } & \multirow{2}{*}{$\begin{array}{l}\text { KD without coronary } \\
\text { artery aneurysm } \\
(n=50), \text { no. }(\%)\end{array}$} & \multicolumn{2}{|c|}{$\begin{array}{l}\text { KD with coronary artery } \\
\text { aneurysm }(n=45)\end{array}$} \\
\hline & & No. (\%) & $\mathrm{aOR}(95 \% \mathrm{CI})$ \\
\hline \multicolumn{4}{|c|}{ IL-10 (-627 A/C) } \\
\hline AA & $34(68.00)$ & $17(37.78)$ & 1.00 \\
\hline $\mathrm{AC}$ & $12(24.00)$ & $22(48.89)$ & $3.67(1.47-9.15)$ \\
\hline $\mathrm{CC}$ & $4(8.00)$ & $6(13.33)$ & $3.00(0.75-12.08)$ \\
\hline $\mathrm{AC}+\mathrm{CC}$ & $16(32.0)$ & $28(62.22)$ & $3.50(1.50-8.16)$ \\
\hline Frequency (A) & 0.80 & 0.62 & \\
\hline
\end{tabular}

$(-627 \mathrm{~A} / \mathrm{C})$ promoter polymorphism is not associated with the development of $\mathrm{KD}$, but may be a risk factor for early development of coronary artery aneurysm.

Previous studies have identified predictors of coronary artery aneurysms in KD patients, including persistent fever after IVIG therapy, low hemoglobin concentration, low albumin concentration, high WBC count, high band count, high CRP concentration, male sex, and age younger than 1 y (34-38). Thus, the profile of a high-risk patient with KD consists of laboratory evidence of increased inflammation combined with demographic features (male sex, age younger than 6 mo or older than 8 y) and incomplete response to IVIG therapy. Our results showed that KD children harboring one or two copies of the $\mathrm{C}$ allele were more frequent than in children homozygous for the A allele and the risk (-627C) allele at the IL-10 promoter polymorphism should potentially be included in this profile.

$\mathrm{KD}$ is a systemic vasculitis with inflammation initially involving increased microvascular permeability in microvessels such as capillaries, arterioles, and venules. Increases in vascular permeability have been associated with hypoalbuminemia and noncardiogenic edema (39), and endothelial permeability has been associated with inflammatory mediators, such as IL-10 and vascular endothelial growth factor (40-43). Thus, our findings that KD children harboring the risk (-627C) allele at the IL-10 polymorphism showed significantly lower albumin levels may form a functional connection between IL-10 and early coronary artery aneurysm.

The present study is somewhat limited by the relatively small study population, the possibility of linkage disequilibrium with an unknown risk single nucleotide polymorphism and the lack of function-related experiments. However, our findings provide preliminary data suggesting that the risk allele of the IL-10 (-627 A/C) promoter polymorphism may be associated with KD risk factors, such as lower albumin level, and the pathogenesis of early coronary artery complications in 
KD patients. These findings suggest that the IL-10 (-627 A/C) promoter polymorphism might prove useful as a genetic marker for the risk of early coronary artery aneurysm in KD and further indicate that the gene encoding IL-10 might prove to be a disease-modifying gene for KD.

\section{REFERENCES}

1. Burns JC, Glode MP 2004 Kawasaki syndrome. Lancet 364:533-544

2. Hirose S, Hamashima Y 1978 Morphological observations on the vasculitis in the mucocutaneous lymph node syndrome. A skin biopsy study of 27 patients. Eur J Pediatr 129:17-27

3. Suzuki A, Kamiya T, Kuwahara N, Ono Y, Kohata T, Takahashi O, Kimura K, Takamiya M 1986 Coronary arterial lesions of Kawasaki disease: cardiac catheterization findings of 1100 cases. Pediatr Cardiol 7:3-9

4. Akagi T, Kato H, Inoue O, Sato N, Imamura K 1990 Valvular heart disease in Kawasaki syndrome: incidence and natural history. Am Heart J 120:366-372

5. Kato H, Sugimura T, Akagi T, Sato N, Hashino K, Maeno Y, Kazue T, Eto G, Yamakawa R 1996 Long-term consequences of Kawasaki disease. A 10- to 21-year follow-up study of 594 patients. Circulation 94:1379-1385

6. Jibiki T, Terai M, Shima M, Ogawa A, Hamada H, Kanazawa M, Yamamoto S, Oana S, Kohno Y 2001 Monocyte chemoattractant protein 1 gene regulatory region polymorphism and serum levels of monocyte chemoattractant protein 1 in Japanese patients with Kawasaki disease. Arthritis Rheum 44:2211-2212

7. Tsukahara H, Hiraoka M, Saito M, Nishda K, Kobata R, Tshchida S, Toyooka M, Kimura H, Gejyo F, Mayumi M 2000 Methylenetetrahydrofolate reductase polymorphism in Kawasaki disease. Pediatr Int 42:236-240

8. Takeuchi K, Yamamoto K, Kataoka S, Kakihara T, Tanaka A, Sato S, Uchiyama M 1997 High incidence of angiotensin I converting enzyme genotype II in Kawasaki disease patients with coronary aneurysm. Eur J Pediatr 156:266-268

9. Ouchi K, Suzuki Y, Shirakawa T, Kishi F 2003 Polymorphism of SLC11A1(formerly NRAMP1) gene confers susceptibility to Kawasaki disease. J Infect Dis 187:326-329

10. Wu SF, Chang JS, Wan L, Tsai CH, Tsai FJ 2005 Association of IL-1Ra gene polymorphism, but no association of IL-1beta and IL-4 gene polymorphisms, with Kawasaki disease. J Clin Lab Anal 19:99-102

11. Biezeveld MH, Geissler J, Weverling GJ, Kuipers IM, Lam J, Ottenkamp J, Kuijpers TW 2006 Polymorphisms in the mannose-binding lectin gene as determinants of age-defined risk of coronary artery lesions in Kawasaki disease. Arthritis Rheum 54:369-376

12. Kariyazono H, Ohno T, Khajoee V, Ihara K, Kusuhara K, Kinukawa N, Mizuno Y, Hara T 2004 Association of vascular endothelial growth factor (VEGF) and VEGF receptor gene polymorphisms with coronary artery lesions of Kawasaki disease. Pediatr Res 56:953-959

13. Nishimura S, Zaitsu M, Hara M, Yokota G, Watanabe M, Ueda Y, Imayoshi M, Ishii E, Tasaki H, Hamasaki Y 2003 A polymorphism in the promoter of the CD14 gene (CD14/-159) is associated with the development of coronary artery lesions in patients with Kawasaki disease. J Pediatr 143:357-362

14. Park JA, Shin KS, Kim YW 2005 Polymorphism of matrix metalloproteinase 3 promoter gene as a risk factor for coronary artery lesions in Kawasaki disease. J Korean Med Sci 20:607-611

15. Furukawa S, Matsubara T, Jujoh K, Yone K, Sugawara T, Sasai K, Kato H, Yabuta K 1988 Peripheral blood monocyte/macrophage and serum tumor necrosis factor in Kawasaki disease. Clin Immunol Immunopathol 48:247-251

16. Matsubara T, Furukawa S, Yabuta K 1990 Serum levels of tumor necrosis factor, interleukin 2 receptor, and interferon gamma in Kawasaki disease involved coronary artery lesions. Clin Immunol Immunopathol 56:29-36

17. Maury CP, Salo E, Pelkonen P 1988 Circulating interleukin-1 in patients with Kawasaki disease. N Engl J Med 319:1670-1671

18. Ueno Y, Takano N, Kanegane H, Yokoi T, Yachie A, Miyawaki T, Taniguchi N 1989 The acute phase nature of interleukin 6: studied in Kawasaki disease and other febrile illness. Clin Exp Immunol 76:337-342

19. Eberhard BA, Andersson U, Laxer RM, Rose R, Silverman ED 1995 Evaluation of the cytokine response in Kawasaki disease. Pediatr Infect Dis J 14:199-203
20. Kim DS, Lee HK, Noh GW, Lee SI, Lee KY 1996 Increased serum interleukin-10 level in Kawasaki disease. Yonsei Med J 37:125-130

21. Hirao J, Hibi S, Andoh T, Ichimura T 1997 High levels of circulating interleukin-4 and interleukin-10 in Kawasaki disease. Int Arch Allergy Immunol 112:152-156

22. Noh GW, Lee WG, Lee W, Lee K 1998 Effects of intravenous immunoglobulin on plasma interleukin-10 levels in Kawasaki disease. Immunol Lett 62:19-24

23. Okada Y, Shinohara M, Kobayashi T, Inoue Y, Tomomasa T, Kobayashi T, Morikawa A. the Gunma Kawasaki Disease Study Group 2003 Effect of corticosteroids in addition to intravenous gamma globulin therapy on serum cytokine levels in the acute phase of Kawasaki disease in children. J Pediatr 143:363-367.

24. Turner DM, Williams DM, Sankaran D, Lazarus M, Sinnott PJ, Hutchinson IV 1997 An investigation of polymorphism in the interleukin-10 gene promoter. Eur J Immunogenet $24: 1-8$

25. Eskdale J, Kube D, Tesch H, Gallagher G 1997 Mapping of the human IL10 gene and further characterization of the $5^{\prime}$ flanking sequence. Immunogenetics 46:120128

26. Eskdale J, Gallagher G, Verweij CL, Keijsers V, Westendorp RG, Huizinga TW 1998 Interleukin 10 secretion in relation to human IL-10 locus haplotypes. Proc Nat Acad Sci U S A 95:9465-9470

27. Hajeer AH, Lazarus M, Turner D, Mageed RA, Vencovsky J, Sinnott P, Hutchinson IV, Ollier WE 1998 IL-10 gene promoter polymorphisms in rheumatoid arthritis. Scand J Rheumatol 27:142-145

28. Grove J, Daly AK, Bassendine MF, Gilvarry E, Day CP 2000 Interleukin 10 promoter region polymorphisms and susceptibility to advanced alcoholic liver disease. Gut 46:540-545

29. Lazarus M, Hajeer AH, Turner D, Sinnott P, Worthington J, Ollier WE, Hutchinson IV 1997 Genetic variation in the interleukin 10 gene promoter and systemic lupus erythematosus. J Rheumatol 24:2314-2317

30. Rosenwasser LJ, Borish L 1997 Genetics of atopy and asthma: the rationale behind promoter-based candidate gene studies (IL-4 and IL-10). Am J Respir Crit Care Med 156:S152-S155

31. Hobbs K, Negri J, Klinnert M, Rosenwasser LJ, Borish L 1998 Interleukin-10 and transforming growth factor-beta promoter polymorphisms in allergies and asthma. Am J Respir Crit Care Med 158:1958-1962

32. Wu KH, Peng CT, Li TC, Wan L, Tsai CH, Lan SJ, Chang MC, Tsai FJ 2005 Interleukin 4, interleukin 6 and interleukin 10 polymorphisms in children with acute and chronic immune thrombocytopenic purpura. Br J Haematol 128:849-852

33. Research Committee on Kawasaki Disease 1984 Report of Subcommittee on Standardization of Diagnostic Criteria and Reporting of Coronary Artery Lesions in Kawasaki Disease. Ministry of Health and Welfare, Tokyo

34. Koren G, Lavi S, Rose V, Rowe R 1986 Kawasaki disease: review of risk factors for coronary aneurysms. J Pediatr 108:388-392

35. Beiser AS, Takahashi M, Baker AL, Sundel RP, Newburger JW 1998 A predictive instrument for coronary artery aneurysms in Kawasaki disease. Am J Cardiol 81:1116-1120

36. Mori M, Imagawa T, Yasui K, Kanaya A, Yokota S 2000 Predictors of coronary artery lesions after intravenous gamma globulin treatment in Kawasaki disease. J Pediatr 137:177-180

37. Morikawa Y, Ohashi Y, Harada K, Asai T, Okawa S, Nagashima M, Katoh T, Baba K, Furusho K, Okuni M, Osano M 2000 Coronary risks after high dose gamma globulin in children with Kawasaki disease. Pediatr Int 42:464-469

38. Honkanen VE, McCrindle BW, Laxer RM, Feldman BM, Schneider R, Silverman ED 2003 Clinical relevance of the risk factors for coronary artery inflammation in Kawasaki disease. Pediatr Cardiol 24:122-126

39. Terai M, Honda T, Yasukawa K, Higashi K, Hamada H, Kohno Y 2003 Prognostic impact of vascular leakage in acute Kawasaki disease. Circulation 108:325-330

40. van Eijk LT, Nooteboom A, Hendriks T, Sprong T, Netea MG, Smits P, van der Hoeven JG, Pickkers P 2006 Plasma obtained during human endotoxemia increases endothelial albumin permeability in vitro. Shock 25:358-362

41. Wang Q, Fang Ch, Hasselgren PO 2001 Intestinal permeability is reduced and IL-10 levels are increased in septic IL-6 knockout mice. Am J Physiol Regul Integr Comp Physiol 281:R1013-R1023

42. Hickey MJ, Issekutz AC, Reinhardt PH, Fedorak RN, Kubes P 1998 Endogenous interleukin-10 regulates hemodynamic parameters, leukocyte-endothelial cell interactions, and microvascular permeability during endotoxemia. Circ Res 83:11241131

43. Dewi BE, Takasaki T, Kurane I 2004 In vitro assessment of human endothelial cell permeability: effects of inflammatory cytokines and dengue virus infection. J Virol Methods 121:171-180 